\title{
Government science and technology budgets in times of crisis
}

ARTICLE in RESEARCH POLICY · APRIL 2013

Impact Factor: 2.85 · DOI: 10.1016/j.respol.2012.10.002

1 AUTHOR:

Teemu Makkonen

University of Surrey

21 PUBLICATIONS 17 CITATIONS

SEE PROFILE 


\title{
Government science and technology budgets in times of crisis
}

\author{
Teemu Makkonen \\ Department of Geosciences and Geography, University of Helsinki \\ Address: PO BOX 64, FI-00014 University of Helsinki, Finland \\ E-mail: teemu.makkonen@helsinki.fi \\ Tel.: + 358919150794 \\ Fax: + 358919150760
}

This is a pre-print version of an article published by Elsevier in Research Policy, Vol. 42, No. 3, pp. 817-822. Available online: http://www.sciencedirect.com/science/article/pii/S0048733312002296

\begin{abstract}
Following a recent paper by Filippetti and Archibugi [Filippetti, A., Archibugi, D., 2011. Innovation in times of crisis: National systems of innovation, structure and demand. Research Policy 40 (2), 179-192], this article aims to contribute to the sparse literature on the impacts of the recent economic downturn on the government expenditures and innovative activities of the countries of the enlarged European Union (EU-27). Using Eurostat's socio-economic objectives i.e. the Nomenclature for the Analysis and Comparison of Scientific Programmes and Budgets (NABS 2007 classification), this paper addresses the impact of the recent economic downturn on governments' science and technology (S\&T) budgets across the 27 EU countries. Most countries followed a pro-cyclical pattern, where the government S\&T budgets in most NABS shrunk along slowing gross domestic product growth in similar pace with total government expenditure. The new member states of Eastern Europe were the most affected.
\end{abstract}

\section{Keywords}

Economic crisis; European Union; Public R\&D funding; S\&T budgets

\section{JEL classification:}

H59; H69; O38 


\section{Introduction}

As Filippetti and Archibugi (2011) point out, the evident lack of participation of economists of innovation in the debate on the causes and impacts of the ongoing economic crisis speaks volumes (also Archibugi and Filippetti, 2011; Paunov, 2012). This likely stems from the lack of timely and updated statistical data. However, now that European statistics officials have updated their databases for the years since the crisis struck, we can estimate the early impacts of the economic crisis. There is a long-standing research on the dynamic of government expenditure over the business cycle (e.g. Afonso and Furceri, 2010; Prasad and Gerecke, 2010). Furthermore, the effects of the recent economic downturn on innovative activities of firms have been investigated (Filippetti and Archibugi, 2011). However, the impact of the European-wide recession on governments' science and technology (S\&T) budgets has not thus far received much attention. Therefore, this paper aims to fill a gap in the literature on the impacts of the recent economic downturn on the S\&T budgets of national governments according to Eurostat's socio-economic objectives i.e. the Nomenclature for the Analysis and Comparison of Scientific Programmes and Budgets (NABS 2007 classification). Thus, this paper aims to repeat the analyses carried out by Filippetti and Archibugi (ibid.), with firmlevel data, but with data on government S\&T budgets. The debate in this paper focuses on reactions to the crisis through the dissonance between the pro-cyclical and counter-cyclical hypotheses of government expenditure and business cycles.

\section{Literature review: Government expenditure and business cycles}

In the literature on government expenditure on innovative activities and business cycles, two opposing hypotheses stand out: 1) pro-cyclical and 2) counter-cyclical. The first, pro-cyclical, hypothesis predicts that expenditures on innovative activities decrease along with a downturn in the economy. The first hypothesis is intuitively clear: a decrease in available economic 
resources will lead to a subsequent decrease in the allocation of these diminishing resources to innovative activities. In fact, following Schumpeterian tradition on investment and innovation over the business cycle (Schumpeter, 1939); Freeman et al. (1982) have claimed that during an economic downturn, the pessimistic mood reduces such investment. The second, counter-cyclical, hypothesis states the direct opposite: that during an economic crisis, expenditures on innovation actually increase; in periods of high gross domestic product (GDP) growth, few resources are allocated to innovative activities, whereas during low growth periods, resource allocation to innovative activities is high (Wälde and Woitek, 2004). Empirically, this would mean that resource allocation to S\&T budgets should correlate negatively with GDP growth rates. The reasoning behind this counter-cyclical hypothesis can be found in the assumption that an economic downturn triggers a greater need to invest in innovation, as nations struggle to once again achieve competitive advantage in order to survive the harsh economic conditions.

In relation to government spendings, during economic downturns, government budgets tend to increase both automatically (social security etc.) and as a consequence of trying to sustain the economy through Keynesian budget-spending policies (e.g. Romer, 1993). However, there is wide regional variation, with developed counties exhibiting the most counter-cyclical spending (Prasad and Gerecke, 2010). Furthermore, in contrast to counter-cyclical Keynesian expenditure patterns, it seems that many countries follow pro-cyclical expenditure patterns (see Lane, 2003a; 2003b; Abbott and Jones, 2012). Pro-cyclicality is often caused by policy reactions driven by the voters (Arestis and Sawyer, 2003; Alesina et al., 2008). For example, during election times all government expenditure categories tend to show an upward drift (van Dalen and Swank, 1996). It should be noted, though, that the empirical evidence on the pro-cyclical or counter-cyclical pattern of government spending is mixed. Thus, although 
several authors have raised the debate of business cycles and government spending to the fore of their analyses, there is no clear consensus on which of the two hypotheses, likely to vary across countries and different types of budgets, is more accurate (e.g. Lee and Sung, 2007; Woo, 2009; Abbott and Jones, 2011; Durevall and Henrekson, 2011).

The above controversy provides the basis for the first research question of the paper: Do the S\&T budgets of governments shrink along with sluggish economic growth (pro-cyclical) or do governments invest more in S\&T during economic crises (counter-cyclical)? This question is further elaborated in accordance with the total public spending of EU nations, to conclude whether the government S\&T budgets are more or less affected than total government expenditure? Recent studies have postulated that in the European context, the crisis affects new member states of the EU and, to some extent, the Southern European countries more due to their vulnerable S\&T infrastructure and financial institutions (Archibugi and Filippetti, 2011; Filippetti and Archibugi, 2011). These notions give rise to the second research question of the paper: In a geographical sense, how do the government S\&T budgets of the $27 \mathrm{EU}$ countries compare with each other in relation to their responses to the economic crisis?

\section{Data and methodology: Government S\&T budgets}

As Richardson et al. (2004) state, a government's primary influence over science comes through the budget. The governments' investment decisions on S\&T are frequently scrutinized in terms of allocation between disciplines, for example, and serve as a tool for competing interests in arguments for increased funding. In fact, the scientific community has been able to successfully argue for more and more funding; an enduring trend of S\&T budgets has been a nearly constant increase in funding (cf. Richardson et al., ibid.; Benavente et al., 2012). In response to the recent economic downturn, however, many European 
governments have had to reduce spending, which will also likely affect government S\&T budgets.

Because good S\&T statistics require the sustained effort of national statistics agencies (Stead, 1992), it is appropriate to use ready-made data provided by official statistics authorities. For this reason, we obtained our data from the databases of Eurostat (2012). The data used here are based on government budget appropriations or outlays for research and development (GBAORD). Previous studies have utilized GBAORD data for measurement and estimates of national S\&T activities (e.g. Niwa and Tomizawa, 1996; Ebersberger, 2005; Moon and Lee, 2005). These data differ from the more commonly used government-financed gross domestic expenditures on research and development (GERD) in two main respects (OECD, 2002; Dinges et al., 2007): 1) government-financed GERD data are based on reports by research and development (R\&D) performers, whereas GBAORD (derived from annual budgetary accounts) are based on reports by funders; 2) the GERD-based series cover only R\&D performed on national territory, whereas GBAORD also includes payments to foreign performers, including international organisations [about 5-20\% of the national S\&T budgets of most countries are allocated to international science activities (Wagner, 2002)]. Here, we used the NABS classification of 2007 (Table 1) to evaluate different socio-economic objectives to provide information on priorities and shifts in public $R \& D$ funding (also OECD, 2003; Dinges et al., 2007). However, it is acknowledged that public R\&D is also likely to be shaped by scientific opportunities and not merely by socio-economic objectives.

<Table 1 about here> 
The data were gathered from 2006-2010. To correspond to the analysis by Filippetti and Archibugi (2011); 2009 served as benchmark year signaling the onset of the recent economic crisis, but with these later data, we carried out comparisons and standard statistical tests between 2010 and a time period preceding the crisis (2006-2008) in order to answer the research questions presented earlier. Unfortunately the data do not cover 2009-2010 for Greece (probably the most interesting country case to investigate in light of the heavy cuts and savings programs imposed to secure state loans). Thus, the response to the crisis in terms of Greece's government S\&T budget is unobservable with the data used here. Additionally, a few individual values (ca. $0.9 \%$ ) are also missing from in the dataset.

\section{Results}

Despite the recent economic downturn, in absolute terms, government S\&T budgets are still growing in many EU countries (Table 2). However, in only a few countries did the growth

pace of government S\&T budgets continue to increase. In most cases, such growth has either leveled off or decreased along with the slowing GDP growth (Table 2). Prior to the crisis, only two countries (Sweden and the United Kingdom) had a negative growth pace of total government S\&T, unlike twelve countries after the crisis struck. A general observation from the data is that, where the total general government expenditure has decreased (Table 2), the S\&T budgets have shrunk accordingly (Fig. 1): the ratio of the S\&T budgets share of the total government expenditure has remained roughly the same in most countries. There were, however, regional variations: some countries exhibited relatively stronger decline in S\&T budgets than in total government expenditures. This applies in particular to Latvia and Lithuania. In Ireland the S\&T budget was cut heavily as a response to the crisis, whereas the total government expenditure has continued to grow (third highest per inhabitant among the EU-27 countries). Still, it seems that, in general, during a recession the S\&T budgets have 
followed more or less the changes in total government expenditure (calculated regression rates vary in the range of $0.90-0.94)$. However, whereas the relationship between GDP and total government expenditure was stable (calculated regression rates vary in the range of 0.97-0.98), the regression rate between S\&T budgets and GDP increased from 0.82 in 2006 to 0.91 in 2010. As such, it suggests a higher relationship as a result of the crisis.

$<$ Table 2 about here>

$<$ Fig. 1 about here>

Examining responses to the crisis on the basis of socio-economic objectives confirms the tentative picture drawn from overall budgets: the percentage of countries where the budget of particular NABS classes decreased after the crisis struck is higher than during the period leading up to the crisis. This observation is evident after subtracting the number of NABS classes where the budget decreased in 2010, compared to 2008, from the number (of NABS classes) where the budget still grew, and then comparing this remainder to the corresponding figures from a time period preceding the crisis (see Table 3). The results indicate that more than $75 \%$ of the countries reduced their S\&T budgets in more NABS classes than they did before the crisis (Fig. 2). Some countries showed the opposite trend, however, meaning that their S\&T budgets for most socio-economic objectives actually grew in 2010. Still, it is fair to say that the evidence seems to support the pro-cyclical more than the counter-cyclical hypothesis.

$<$ Table 3 about here>

<Fig. 2 about here> 
When measured according to government S\&T budgets, the countries most affected by the crisis were Belgium, the Czech Republic, Estonia, Ireland, Italy, Latvia, Luxembourg, Romania and Spain (Fig. 3). Of these, the East European new member states were growing (converging) their S\&T budgets at the fastest rate prior to the crises. In Belgium, Estonia, Ireland, Italy, Latvia, Romania and Spain, this has resulted in an absolute drop in the overall S\&T budget, whereas in the Czech Republic and Luxembourg, the overall budgets grew, but the growth was directed to a limited number of NABS classes. In the United Kingdom, the decline in S\&T budgets began even before the crisis hit. What is common among all these countries is that they exhibited a strong pro-cyclical pattern in response to the crisis: an absolute drop in the overall S\&T budget and/or a decline in the number of growing NABS classes. In Sweden, the remainder of growing NABS classes and the overall S\&T budget grew slightly compared to the strong drop prior to the crisis. With its steady increase in the S\&T budgets of its NABS classes both prior to and after the crisis Germany ranks in a league of its own, whereas Hungary and Lithuania have witnessed a relatively stable decline, according to their NABS classes, and an overall drop in their S\&T budgets.

$<$ Fig. 3 about here>

In conclusion, the results presented here provide stronger evidence supporting the procyclical hypothesis as well as the earlier notions of Archibugi and Filippetti (2011) and Filippetti and Archibugi (2011). In general, the S\&T budgets have followed the trends of total government expenditure. In terms of S\&T budgets, the crisis seems to have affected the new member states of Eastern Europe and, to some extent, the Southern European countries plus Ireland more than other EU member states. 


\section{Discussion and implications}

As the economic downturn has made banks, markets and investors more risk averse, firms have difficulty securing external funding to support their innovation activities, a major concern in the recent context (OECD, 2009). Guellec and Ioannidis (1999), for example, have concluded that in the long run the reduction of government funding explains also much of the reduction in business $\mathrm{R} \& \mathrm{D}$ expenditures. Thus, the importance of government support and S\&T investment in helping firms to counteract the negative impacts of economic crises on innovation investments grows (Paunov, 2012). In most cases, however, government responses to economic crises are also pro-cyclical. As a short-term implement, understandably nations must cut spending in order to comply with halted or reduced economic growth. However, the key to surviving an economic crisis lies in a nation's ability to find new ways of doing things (i.e. to innovate). Political reactions to economic downturns that hamper innovation may do far more harm than good; economic growth requires policies that encourage innovation (Acemoglu, 2009). If, say a crisis from within in the private sector is discharging $\mathrm{R} \& \mathrm{D}$ personnel, the public sector should try to counteract the trend and provide, at least in the short period, alternative employment (e.g. Stiglitz, 1999).

Drawing from the Schumpeterian (1942) notion of 'creative destruction', new innovations will play a central role in the renewed economic growth following a crisis. Moreover, 'creative reconstruction', in terms of targeted counter-cyclical government intervention and public venture capital to firms, is also needed to develop new innovation mechanisms (Etzkowitz, 2005). It is vital that the public sector continues to provide incentives for the private sector. Finland, for example, which faced a serious economic crisis in the beginning of the 1990s, responded to this by increasing rather than decreasing government spending in support of innovative activities. This proved to be a significant factor in Finland's strong 
rebound after the crises of the 1990s (OECD, 2009). What followed was an increase in the productivity of Finnish industry and the Schumpeterian restructuring of the Finnish economy, where knowledge-based information and communications industries replaced resource-based heavy industries as the leading sector of its national economy (Jonung et al., 2009). In short, as earlier experiences have shown, governments' pro-cyclical reaction to crises by reducing their S\&T spending may turn out poorly in the long run. Still, close investigation of which projects are feasible and which are not ('picking winners') is necessary to minimize the inefficient use of government funds; clear objectives and criteria for this selection process are recommended (see Etzkowitz and Ranga, 2009).

\section{Conclusions}

This paper aimed to explore changes in governments S\&T budgets in response to the recent economic crisis in the geographical context of the enlarged European Union (EU-27). The data were arranged according to the NABS 2007 classification of Eurostat, signaling discrete socio-economic objectives, both before and after the crisis struck. We tested two opposing hypotheses: pro-cyclical and counter-cyclical. The negative impact of the recent economic crisis on the total government expenditure (and GDP growth) was mirrored, in general, as such in the S\&T budgets. In a limited few countries, the response was counter-cyclical; in Sweden, for example, the number of NABS classes that increased changed from negative to positive after the crisis struck. However, the evidence points more toward the pro-cyclical hypothesis i.e. that government S\&T spending decreases in response to the crisis.

In general, the countries most affected were, to some extent, the Southern European countries (particularly Spain and Italy have been struggling to reduce their level of public debt after the tensions in the financial market) plus Ireland, but in particular the new member states of 
Eastern Europe (i.e. countries in Europe with the lowest levels of social security and public expenditure): the prior-crisis convergence in terms of their S\&T expenditures has leveled off. In this sense, the crisis was less likely to affect those countries with robust financial systems and strong governmental support for innovation activities prior to the crisis. Our results are in line with those of earlier studies with firm-level data (cf. Archibugi and Filippetti, 2011; Filippetti and Archibugi, 2011). Therefore, an interesting avenue for further thought would be to explore more the interaction between trends in the public and the business sectors. As for policy recommendations, this paper draws from earlier experiences, to conclude that implementing deep reductions in S\&T budgets may be a poor long-term strategy. Rather, sustained government S\&T budgets are more apt to counteract the negative impacts of economic crises.

The data used have some limitations, as they were obtained during a relatively small period; a lengthier period would have contributed to a more precise picture. This is a task for further studies, when more comprehensive data become available. Furthermore, the strict concentration on the $27 \mathrm{EU}$ countries and the unavailability of current data for Greece remain shortcomings for further investigations to overcome. At the moment, however, similar data on non-EU countries are currently largely unavailable.

\section{Acknowledgements}

This study is part of the Academy of Finland funded project no. 127213. I am grateful to Professor Tommi Inkinen, Dr. Gareth Rice and to the anonymous reviewers for their comments on improving the paper. 


\section{References}

Abbott, A., Jones, P., 2011. Procyclical government spending: Patterns of pressure and prudence in the OECD. Economic Letters $111(3), 230-232$.

Abbott, A., Jones, P., 2012. Intergovernmental transfers and procyclical public spending. Economic Letters 115 (3), 447-451.

Acemoglu, D., 2009. The crisis of 2008: Lessons for and from economics. Critical Review: A Journal of Politics and Society $21(2-3), 185-194$.

Afonso, A., Furceri, D., 2010. Government size, composition, volatility and economic growth. European Journal of Political Economy 26 (4), 517-532.

Alesina, A., Campante, F., Tabellini, G., 2008. Why is fiscal policy often procyclical? Journal of the European Economic Association 6 (5), 1006-1036.

Archibugi, D., Filippetti, A., 2011. Is the economic crisis impairing convergence in innovation performance across Europe? Journal of Common Market Studies 49 (6), 1153-1182.

Arestis, P., Sawyer, M., 2003. Reinventing fiscal policy. Journal of Post Keynesian Economics 26 (1), 3-25.

Benavente, J.M., Crespi, G., Garone, L.F., Maffioli, A., 2012. The impact of national research funds: A regression discontinuity approach to the Chilean FONDECYT. Research Policy 41 (8), 1461-1475.

Dinges, M., Berger, M., Frietsch, R., Kaloudis, A., 2007. Monitoring sector specialisation of public and private funded business research and development. Science and Public Policy 34 (6), 431-443.

Durevall, D., Henrekson, M., 2011. The futile quest for a grand explanation of long-run government expenditure. Journal of Public Economics 95 (7-8), 708-722.

Ebersberger, B., 2005. The Impact of Public R\&D Funding. VTT Technical Research Centre of Finland, Espoo.

Etzkowitz, H., 2005. The renewal of venture capital: Toward a counter-cyclical model. Technology Analysis \& Strategic Management 17 (1), 73-87.

Etzkowitz, H., Ranga, M., 2009. A trans-Keynesian vision of innovation for the contemporary economic crisis: 'Picking winners’ revisited. Science and Public Policy 36 (10), 799-808.

Eurostat, 2008. Comparison between NABS 2007 and NABS 1992 (downloaded on 29 February 2012 from http://www.oecd.org/dataoecd/62/38/43299905.pdf).

Eurostat, 2012. Statistics Database (downloaded on 30 August 2012 from http://epp.eurostat.ec.europa.eu/).

Filippetti, A., Archibugi, D., 2011. Innovation in times of crises: National systems of innovation, structure and demand. Research Policy 40 (2), 179-192. 
Freeman, C., Clark, J., Soete, L., 1982. Unemployment and Technical Innovation: A Study of Long Waves and Economic Development. Pinter, London.

Guellec, D., Ioannidis, E., 1999. Causes of fluctuations in R\&D expenditures: A quantitative analysis. OECD Economic Studies 29 (2), 124-138.

Jonung, L., Kiander, J., Vartia, P. (Eds), 2009. The Great Financial Crisis in Finland and Sweden: The Nordic Experience of Financial Liberalization. Edward Elgar Publishing, Cheltenham.

Lane, P., 2003a. Business cycles and macroeconomic policy in emerging market economies. International Finance $6(1), 89-108$.

Lane, P., 2003b. The cyclical behaviour of fiscal policy: Evidence from the OECD. Journal of Public Economics 87 (12), 2661-2675.

Lee, Y., Sung, T., 2007. Fiscal policy, business cycles and economic stabilisation: Evidence from industrialised and developing countries. Fiscal Studies 28 (4), 437-462.

Moon, H-S., Lee, J-D., 2005. A fuzzy set theory approach to national composite S\&T indices. Scientometrics 64 (1), 67-83.

Niwa, F., Tomizawa, H., 1996. A trial of general indicator of science and technology: Methodological study of overall estimation of national S\&T activity. Scientometrics 37 (2), 245-265.

OECD, 2002. Frascati Manual: Proposed Standard Practice for Surveys on Research and Experimental Development. OECD Publications, Paris.

OECD, 2003. OECD Science, Technology and Industry Scoreboard. OECD Publications, Paris.

OECD, 2009. Policy Responses to the Economic Crisis: Investing in Innovation for Long-Term Growth (downloaded on 12 March 2012 from http://www.oecd.org/dataoecd/59/45/42983414.pdf).

Paunov, C., 2012. The global crisis and firms' investments in innovation. Research Policy 41 (1), 24-35.

Prasad, N., Gerecke, M., 2010. Social security spending in times of crisis. Global Social Policy 10 (2), $218-247$.

Richardson, J., Matson, W., Peters, R., 2004. Innovating science policy: Restructuring S\&T policy for the twenty-first century. Review of Policy Research 21 (6), 809-828.

Romer, D., 1993. The new Keynesian synthesis. Journal of Economic Perspectives 7 (1), 5-22.

Schumpeter, J., 1939. Business Cycles: A Theoretical, Historical and Statistical Analysis of the Capitalist Process. McGraw-Hill Book Company, New York.

Schumpeter, J., 1942. Capitalism, Socialism and Democracy. Harper, New York.

Stead, H., 1992. Collection of S\&T statistics. Science and Public Policy 19 (5), 275-280. 
Stiglitz, J., 1999. Responding to economic crises: Policy alternatives for equitable recovery and development. Manchester School 67 (5), 409-427.

van Dalen, H., Swank, O., 1996. Government spending cycles: Ideological or opportunistic? Public Choice 89 (1-2), 183-200.

Wagner, C., 2002. The elusive partnership: Science and foreign policy. Science and Public Policy 29 (6), 409417.

Wälde, K., Woitek, U., 2004. R\&D expenditures in G7 countries and the implications for endogenous fluctuations and growth. Economic Letters 82 (1), 91-97.

Woo, J., 2009. Why do more polarized countries run more procyclical fiscal policy? Review of Economics and Statistics 91 (4), 850-870.

\section{FIGURES}

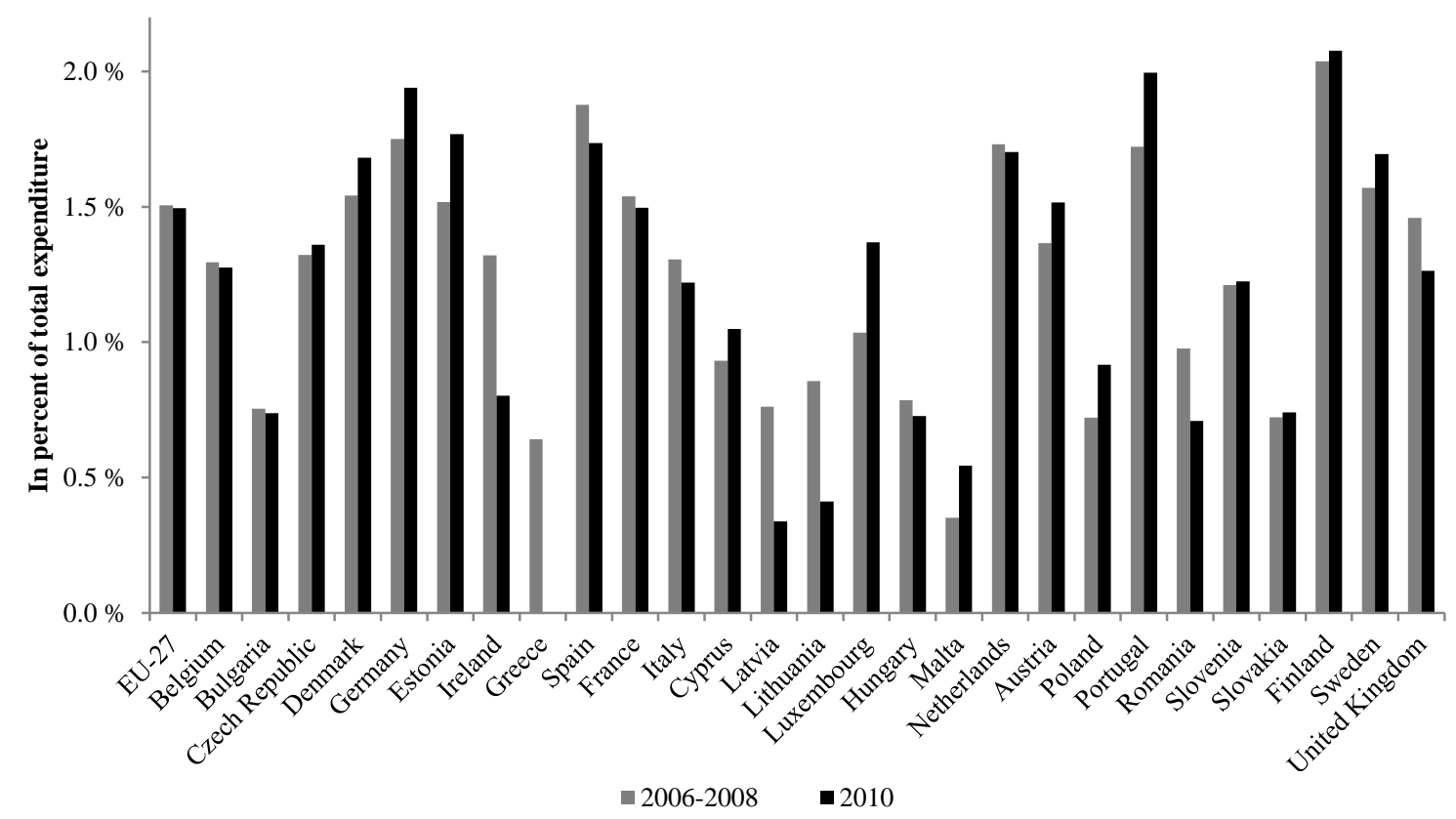

Fig 1. Government S\&T budget as a percentage of total government expenditure by country; 2006-2008 and 2010. Source: author's elaboration on Eurostat (2012) data. 
EU-27 (except Greece)

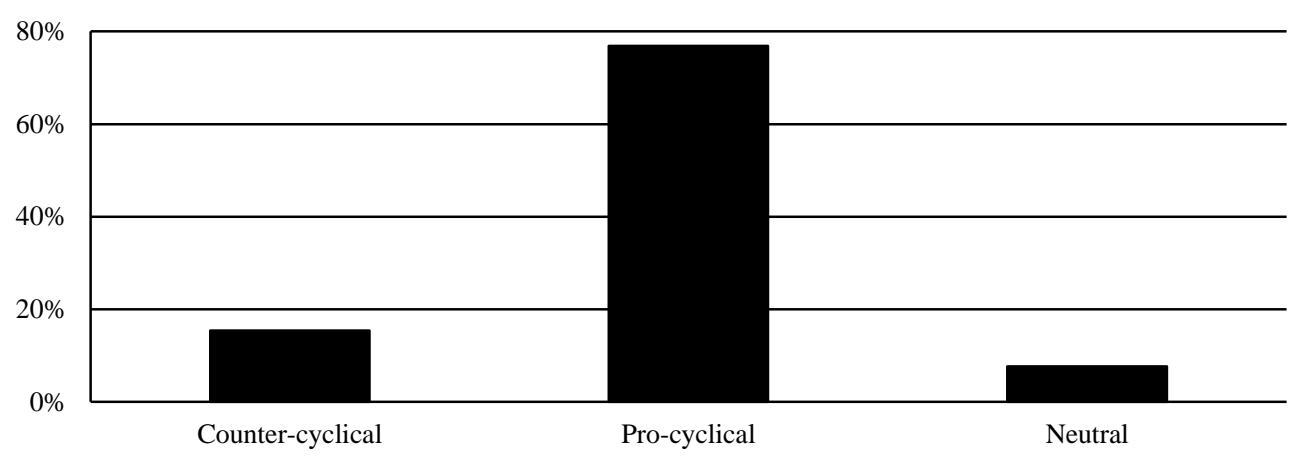

Fig 2. Government S\&T budget behavior (country-wise) in response to the crisis.

Source: author's elaboration on Eurostat (2012) data.

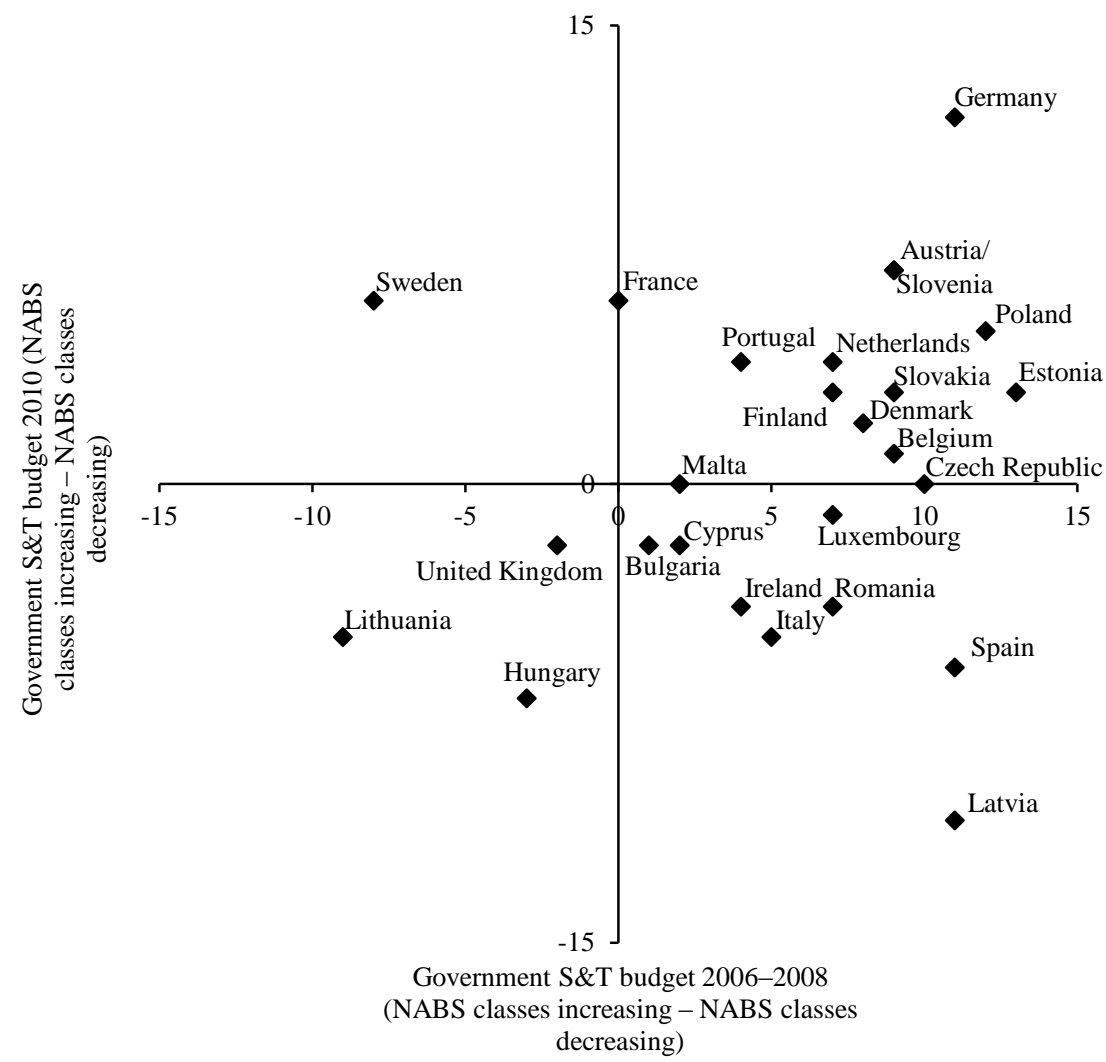

Fig 3. The balances of government investment and disinvestment in S\&T before and after the crisis. Source: author's elaboration on Eurostat (2012) data. 
TABLES

Table 1

Eurostat's Nomenclature for the Analysis and Comparison of Scientific Programmes and Budgets (NABS) 2007 classification.

1) Exploration and exploitation of the earth

2) Environment

3) Exploration and exploitation of space

4) Transport, telecommunication and other infrastructures

5) Energy

6) Industrial production and technology

7) Health

8) Agriculture

9) Education

10) Culture, recreation, religion and mass media

11) Political and social systems, structures and processes

12) General advancement of knowledge: R\&D financed from General University Funds (GUF)

13) General advancement of knowledge: R\&D financed from sources other than GUF

14) Defense

Source: Eurostat (2008). 
Table 2

Country-specific statistics on S\&T budgets (GBAORD), total general government expenditure and GDP.

\begin{tabular}{|c|c|c|c|c|c|c|c|c|c|}
\hline \multirow[b]{2}{*}{ GEO/TIME } & \multicolumn{3}{|c|}{$\begin{array}{c}\text { Total government budget appropriations or } \\
\text { outlays for R\&D } \\
\text { (Euro per inhabitant) }\end{array}$} & \multicolumn{3}{|c|}{$\begin{array}{l}\text { Total general government expenditure } \\
\text { (Euro per inhabitant) }\end{array}$} & \multicolumn{3}{|c|}{$\begin{array}{l}\text { Gross domestic product } \\
\text { (Euro per inhabitant) }\end{array}$} \\
\hline & 2006 & 2008 & 2010 & 2006 & 2008 & 2010 & 2006 & 2008 & 2010 \\
\hline EU-27 & 163 & 179 & 185 & 10954 & 11778 & 12367 & 23700 & 25000 & 24400 \\
\hline Belgium & 185 & 220 & 219 & 15251 & 16098 & 17188 & 30200 & 32299 & 32700 \\
\hline Bulgaria & 10 & 14 & 13 & 1597 & 1780 & 1791 & 3400 & 4600 & 4800 \\
\hline Czech Republic & 63 & 79 & 85 & 5244 & 6086 & 6262 & 11500 & 14800 & 14200 \\
\hline Denmark & 292 & 364 & 413 & 21172 & 22059 & 24563 & 40200 & 42800 & 42500 \\
\hline Germany & 214 & 240 & 281 & 12846 & 13268 & 14503 & 28100 & 30100 & 30500 \\
\hline Estonia & 50 & 78 & 77 & 4068 & 4801 & 4336 & 10000 & 12200 & 10700 \\
\hline Ireland & 188 & 215 & 185 & 15929 & 17347 & 23074 & 41800 & 40500 & 34900 \\
\hline Greece & 62 & 62 & $\mathrm{n} / \mathrm{a}$ & 9471 & 10498 & 10091 & 18700 & 20700 & 20100 \\
\hline Spain & 154 & 186 & 181 & 9203 & 9891 & 10411 & 22400 & 23900 & 22800 \\
\hline France & 231 & 265 & 253 & 15563 & 16058 & 16901 & 28400 & 30100 & 29900 \\
\hline Italy & 155 & 167 & 158 & 12468 & 12795 & 12970 & 25300 & 26300 & 25700 \\
\hline Cyprus & 62 & 92 & 100 & 8383 & 9114 & 9569 & 19400 & 21500 & 20600 \\
\hline Latvia & 19 & 30 & 13 & 3321 & 3948 & 3757 & 7000 & 10100 & 8600 \\
\hline Lithuania & 23 & 25 & 14 & 2949 & 3595 & 3428 & 7100 & 9700 & 8400 \\
\hline Luxembourg & 237 & 365 & 462 & 28338 & 29989 & 33739 & 71800 & 80800 & 79500 \\
\hline Hungary & 33 & 45 & 35 & 5012 & 5174 & 4803 & 8900 & 10500 & 9700 \\
\hline Malta & 20 & 22 & 35 & 5694 & 6228 & 6367 & 12500 & 14200 & 14800 \\
\hline Netherlands & 234 & 253 & 309 & 15804 & 16714 & 18134 & 33100 & 36200 & 35400 \\
\hline Austria & 206 & 239 & 272 & 16044 & 16733 & 17953 & 31300 & 33900 & 34100 \\
\hline Poland & 23 & 29 & 39 & 3442 & 4115 & 4215 & 7100 & 9500 & 9300 \\
\hline Portugal & 106 & 140 & 166 & 7081 & 7254 & 8320 & 15200 & 16200 & 16200 \\
\hline Romania & 15 & 26 & 17 & 2214 & 2553 & 2327 & 4500 & 6500 & 5800 \\
\hline Slovenia & 87 & 94 & 106 & 7272 & 8156 & 8687 & 15500 & 18400 & 17300 \\
\hline Slovakia & 22 & 33 & 36 & 3475 & 4161 & 4849 & 8300 & 11900 & 12100 \\
\hline Finland & 322 & 342 & 386 & 16128 & 17231 & 18590 & 31500 & 34900 & 33300 \\
\hline Sweden & 296 & 290 & 331 & 18823 & 18701 & 19541 & 35000 & 36100 & 37200 \\
\hline United Kingdom & 214 & 192 & 174 & 14775 & 14031 & 13801 & 32299 & 29500 & 27500 \\
\hline
\end{tabular}


Table 3

Change in government S\&T budgets in response to the crisis vis-à-vis the period before the crisis.

Counter-cyclical

Pro-cyclical

Neutral

Countries where the remainder between NABS classes with growing budgets compared to those with shrinking budgets was higher in 2010 than before the crisis

Countries where the remainder between NABS classes with growing budgets compared to those with shrinking budgets was lower in 2010 than before the crisis

Countries where the remainder between NABS classes with growing budgets compared to those with shrinking budgets was the same in 2010 than before the crisis 